\title{
SWOT ANALYSIS OF ART PERFORMANCE AS CITY PROMOTIONAL STRATEGY IN YOGYAKARTA
}

\author{
HADI SUBAGYO \\ Institut Seni Indonesia Surakarta, \\ Jl. Ki Hajar Dewantara No. 19 Surakarta, Jawa Tengah, Indonesia 57126 \\ E-mail: hadisubagyo1956@gmail.com \\ ORCID :https://orcid.org/0000-0001-6798-1251 \\ CAHYANI TUNGGAL SARI \\ Sekolah Tinggi Ilmu Ekonomi Adi Unggul Bhirawa, Surakarta, \\ Jl. Mr. Sartono No. 46, Nusukan, Banjarsari, Surakarta 57135 \\ E- mail: cahyani031084@gmail.com \\ ORCID: https://orcid.org/0000-0002-7616-8964
}

\begin{abstract}
Aim. Yogyakarta, a famous city in Indonesia, is well known for the Prambanan temple and its Ramayana Ballet performance. As the cultural and culinary city, Yogyakarta has been indirectly promoted by its cultural performances, such as Ramayana Ballet. The aims of the study were to identify the strengths, weaknesses, opportunities, and threats related to Ramayana Ballet Prambanan as a promotion strategy medium in Yogyakarta.

Methods. This study used a historical approach in understanding the art performance in Ramayana Ballet Prambanan. Besides, this study used the data of tourists' visits to Ramayana Ballet Prambanan, Yogyakarta.

Results. This research shows that even though there are not many strengths of the Ramayana Ballet art performance, the opportunities related to this kind of promotional strategy compensate for the weaknesses and the threats.

Conclusion. We can conclude that Ramayana Prambanan as an example of performance art in Yogyakarta has a positive value and provides a significant contribution to Yogyakarta tourism. These can be seen from the increase of tourist visitors to Ramayana art performance from 2008 to 2016. The art performance has become one of many promotional strategy choices in Yogyakarta.
\end{abstract}

Key words: SWOT Analysis, Art Performance, Promotional Strategy 


\section{INTRODUCTION}

$\mathrm{T}$ he approach towards business economics adopted in this study is based on the philosophy of art marketing. It is assumed that in art marketing, there are two dominant philosophies, and more specifically: Art for Art and Art for Mart. Art for Art means art for art. The artists who adhere to this view tend to treat their works as a realization of themselves. They will not take into account whether the market or the community needs the work or not.

Art for Mart means art for the market. In other words, the art performers act in accordance with the tastes of the market. Consequently, the market has an effect on what the artist do. The selection of this philosophy is important for the organizations of performing arts or artists because - by following this philosophy - the organizations will be able to satisfy: 1) the audience; 2) the community; 3) the government; 4) the artists; 5) the employees; and 6) the shareholders (Permas et al., 2003).

As works of culture, performing arts primarily function in three areas, and namely: education, economics, and ideology. The educational aspect implies that performing arts should be treated as a tool for 'educating', either directly or indirectly. However, there has recently been a functional change narrowing the purpose of the performing arts to the spectacle alone. The meaning of the show has changed towards orientation or interest alone. In terms of ideological aspects, performing arts are a part of the national cultural identity. These three areas (education, economics, and ideology) are related to one another. The community is dynamic, and the dynamics of the society can influence the dynamics of culture and art (Christie, 1990).

Langley (1974) mentions that the purpose of commercial theatre is to support life and obtain self-esteem. The commercial term refers to one of the economic systems of production of performing arts. Langley argues that the art form of organization is based on four criteria, and more specifically: (1) explicit purpose; (2) quality standard; (3) work motivation; and (4) potential artist or artists. The most important commercial aspect of performing arts are market consumers. Critics explain the desires of the producers, and only competent artists are able to imitate, interpret and modify these conditions.

\section{METHODS}

This research is a qualitative descriptive research conducted with the use of historical and economic research methodology. The historical approach is considered most adequate in revealing background, causality, developmental patterns, and the phenomena of historical events, concerning cultural, political, economic, and social events . In order to obtain clarity in this matter, the current study follows the instructions and rules that must be followed in any research which uses historical methods.

According to Garraghan, there are three major steps to be taken in historical research method (Muhadjir, 2000): (1) heuristics, that is a process of collecting historical sources in accordance with the object of the problem. Data come from 
a variety of resources, such as reports, magazines, manuscripts, archives, book chapters, and oral data obtained in interviews; (2) source criticism, that is a step taken to verify the truth of the obtained information. External criticism is used to obtain source authenticity, whereas internal criticism is used to gain the credibility of the source. This step is very important to do in historical research; and (3) interpretation, that is performed by correlating the historical facts that have been selected. This stage is conducted after combining two sources. Besides, this study also uses SWOT analysis in comparing the promotion of the use of art performance strategy in promoting a city, and especially the city of Yogyakarta.

\section{RESULT AND DISCUSSION}

The tourism industry will give birth to the art of performing the shows which are deliberately designed for tourists. The art of packaging is a new phenomenon whose format will adjust to the conditions of tourists. The characteristics of the performing arts tours include: 1 ) an imitation of existing traditions; 2) brief and dense presentation; 3) variations and attractions, prepared in accordance with tourists' appetite; 4) putting aside the sacred, magical, and symbolic values; 5) calculation of the presentation cost so that the 'selling price' would be affordable for tourists. These characteristics could serve as a benchmark for the form of tourist art that is very relative in nature. Soedarsono said, that the development of tourism industry was able to enrich the cultural treasures of the nation. Before the development of the tourism industry, art and culture only satisfied the needs of local communities, and when there is interaction with foreign tourists, the presented art is a new packaging for the benefit of tourism. Graburn calls this phenomenon the art of acculturation, and Soedarsano - pseudo-traditional art. This art of acculturation, in general terms, is referred to as tourist art or tourist art (Soedarsono, 2003).

Ramayana Ballet dance performances are presented to tourists on the basis of a flexible policy, as an effort to adjust to the context of both function and era. Creative ideas in the development of dance arts are necessary to preserve the traditional culture while ensuring that the heritage of past cultural values is the basis for a new culture.

\section{SWOT Analysis}

The analysis of internal and external factors in an organization or company, better known as SWOT (strength, weakness, opportunity, threat), is a method widely used to determine the internal and external situations and conditions faced by the organization (Robbins, et al., 2000).

\section{Strengths:}

- Performing arts can attract tourists.

Performing arts have a unique potential in attracting the international tourist, especially in the case of Ramayana Prambanan performing arts, 
which shows the story of Rama and Shinta. Besides, the colosal performing art shows on the open stage involve many people as dancers. As the shows are considered spectacular, the audience has to book in advance, if they want to get the best seat for watching.

- Performing arts do not need much promotional expenses.

Performing arts as a promotional strategy is not too costly when compared with other media, such as television advertising or printed media. Many tourists who see the performing arts in Yogyakarta, and especially Ramayana Ballet Prambanan, describe their experience in social media and online blogs. This is profitable for the Ramayana Ballet management as a free promotional strategy.

\section{Weaknesses:}

- No traditional performances in the national and international language. A weakness of traditional performing arts involves using traditional Javanese Language in the dialogues, and many tourists do not understand this language. Consequently, some of them need a translator, and some of them cannot enjoy the show because of the language barrier.

- The same scene for every show.

Ramayana Ballet art performance is based on the story of the old civilization. Traditional Javanese dances and music need to be adjusted to the rules of ballet. Therefore, the Ramayana Ballet show does not have much variation because modern artistic variations would impact the traditional image of the Ramayana Ballet show.

- Outdated costumes.

Not all the groups that perform the Ramayana ballet have sufficient funds to make new costumes with the aid of good materials. Most of them still use old-fashioned costumes.

- Cadre deficiency.

Nowadays, young people prefer modern art and spend much time using social media. Few of them wish to learn traditional dances. Ramayana Ballet Prambanan needs to take a great effort in preparing the next generation of Ramayana Ballet performers. They have to introduce innovations in the show in order to make young people interested in learning traditional dances.

\section{Opportunities:}

- Tour packaging.

Tour and Travel agents provide many tour package choices for tourist visiting Yogyakarta. Some examples of such tour packages involve: nature tour package, art tour package, shopping tour package, education tour package, etc. Ramayana Prambanan with its traditional art performance has become one of the preferred tourist destinations.

- Some cities do not have interesting art performances.

Yogyakarta could be considered a 'lucky' city that has an open air stage 
with the Prambanan temple in the background, and thus can hold Ramayana Ballet performance on it. The view from the open air stage is very instagrammable and best for photoshooting.

- Improve the surrounding economically.

The existence of Ramayana Ballet Prambanan has financially contributed to the community around Prambanan Temple who are involved in the show.

- The development of online technology.

The growth of online technology has given opportunity for Ramayana Ballet Prambanan management to spread out the information about Ramayana Ballet Prambanan online.

\section{Threats}

- The increase of modern performing arts.

The growth of the modern culture and performing arts make Ramayana Ballet Prambanan an alternative for other performing arts in Yogyakarta, such as modern music, modern dance, street dance performing arts, etc.

The Ramayana Ballet Prambanan has to use crative strategies so that it could compete with the others.

- Alternative tourist destinations.

Yogyakarta now has many new tourist attractions, such as the beach and other new natural tourist destination.

- The increase art performance tourism destinations in other cities.

- Natural disaster

In 2006, Yogyakarta has experienced the Merapi mountain eruption. This event made tourists afraid to come to Indonesia

Table 1.

SWOT Analysis of using Art Performance as Promotional Strategy

\begin{tabular}{|c|c|}
\hline Strengths & Weaknesses \\
\hline $\begin{array}{ll}\text { Sa. } & \text { Performing arts can attract tourists } \\
\text { Sb. } & \text { No need of promotional expenses. }\end{array}$ & $\begin{array}{l}\text { Wa. The lack of traditional } \\
\text { performances in the national } \\
\text { language. } \\
\text { Wb. The same scene for every show. } \\
\text { Wc. Outdated dancers' costumes. } \\
\text { Wd. Cadre deficiency. }\end{array}$ \\
\hline Opportunities & Threats \\
\hline $\begin{array}{l}\text { Oa. Tour packaging. } \\
\text { Ob. Some cities do not have interesting } \\
\text { art performances. } \\
\text { Oc. Improve the surrounding } \\
\text { economically } \\
\text { Od. The development of online } \\
\text { technology. }\end{array}$ & $\begin{array}{l}\text { Ta. The development of modern } \\
\text { culture } \\
\text { Tb. Alternative tourist destinations. } \\
\text { Tc The increase of other city art } \\
\text { performance tourism destination. } \\
\text { Td. Natural disasters. }\end{array}$ \\
\hline
\end{tabular}

Source : Robbins and David (2000) 
Journal of Education Culture and Society No. 1_2020

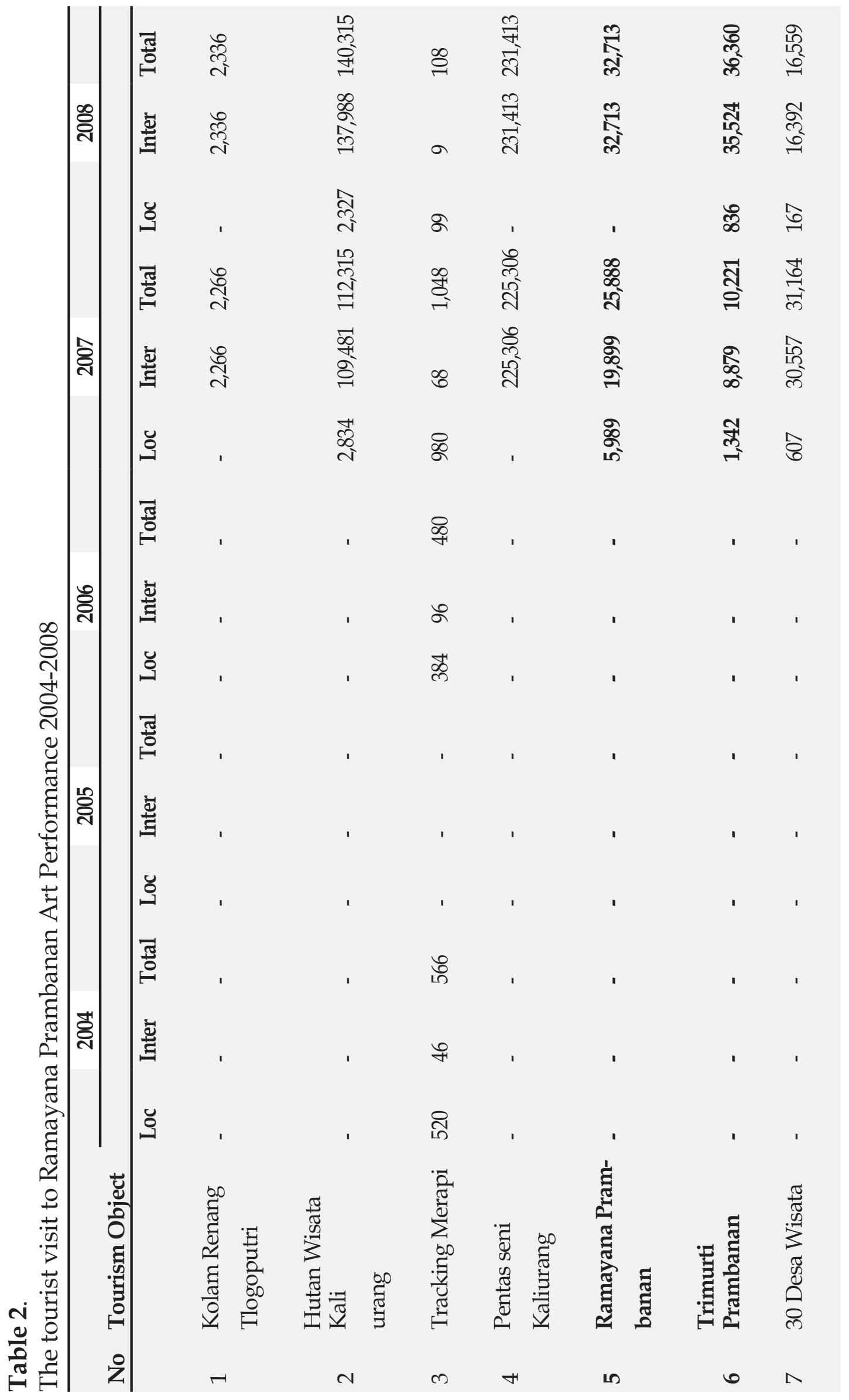




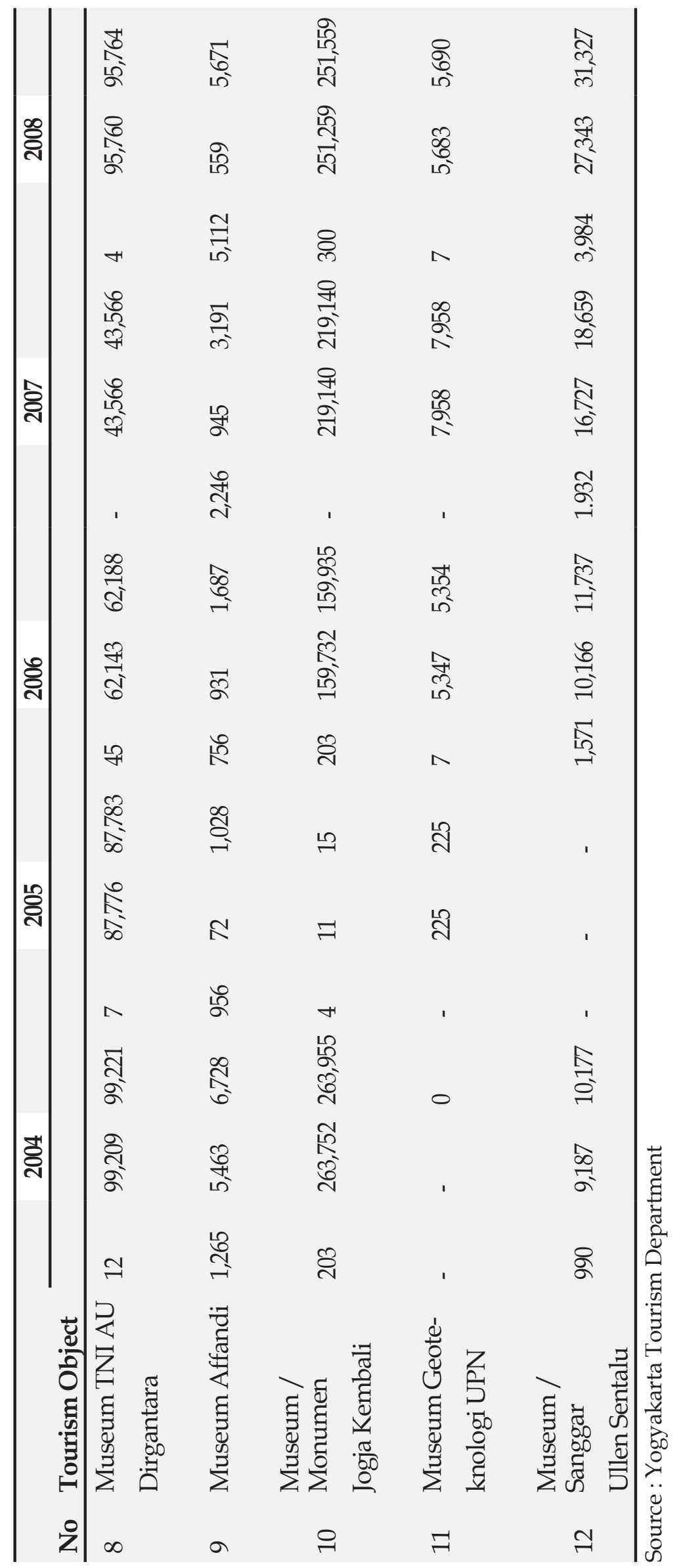




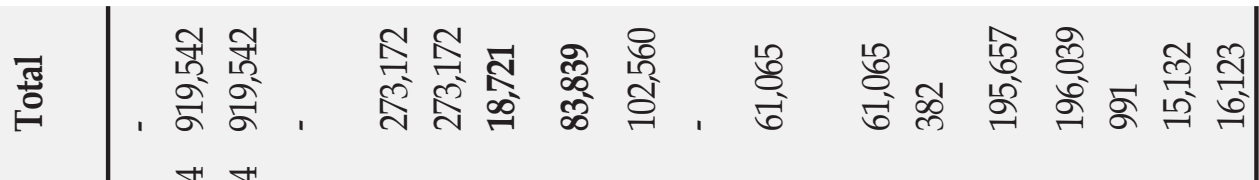

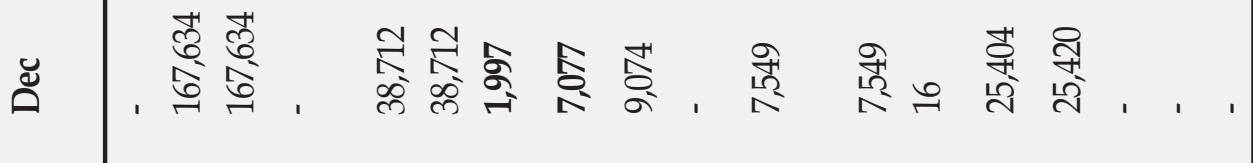

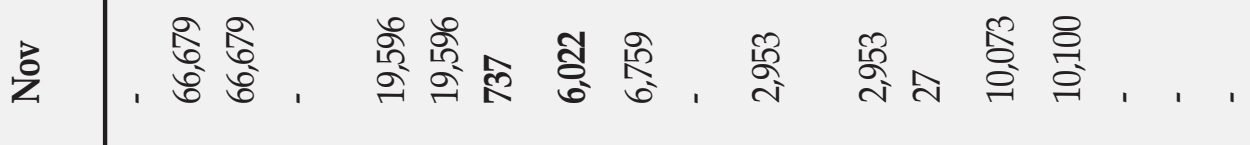

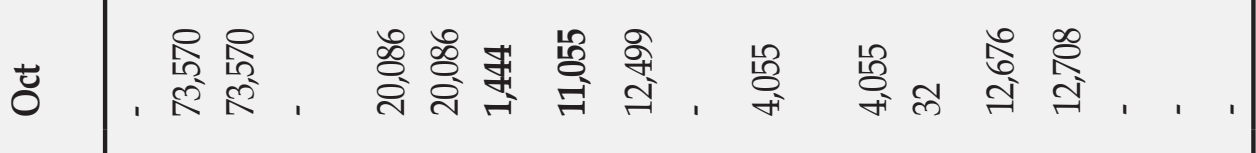

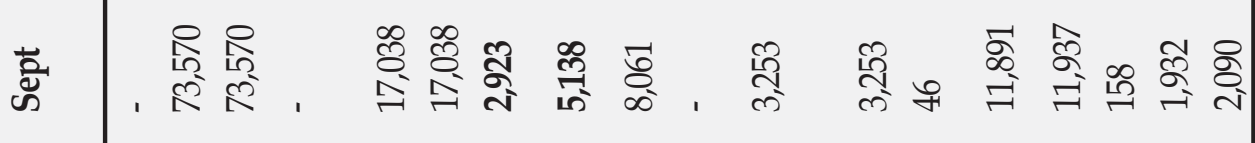

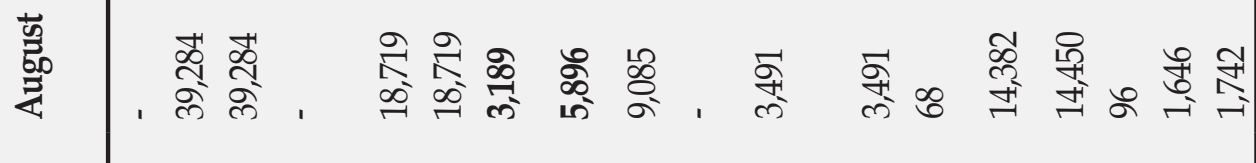

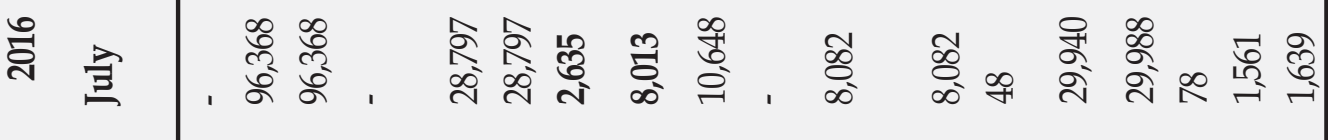

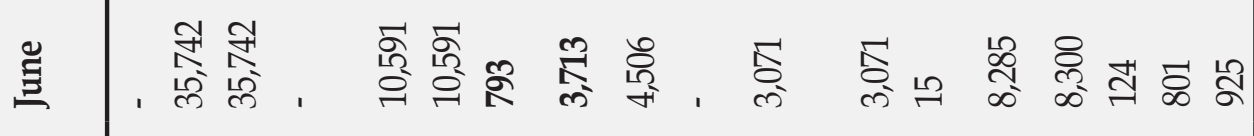

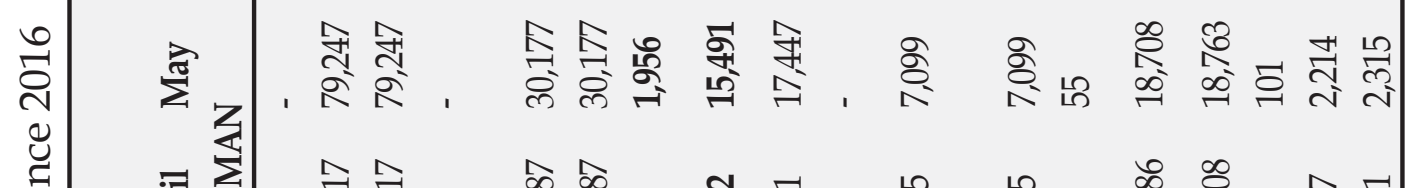

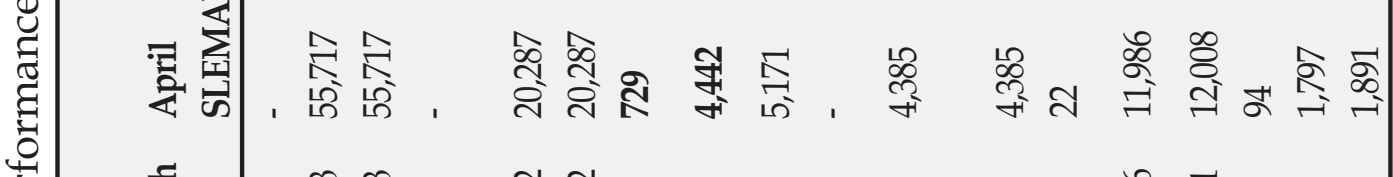

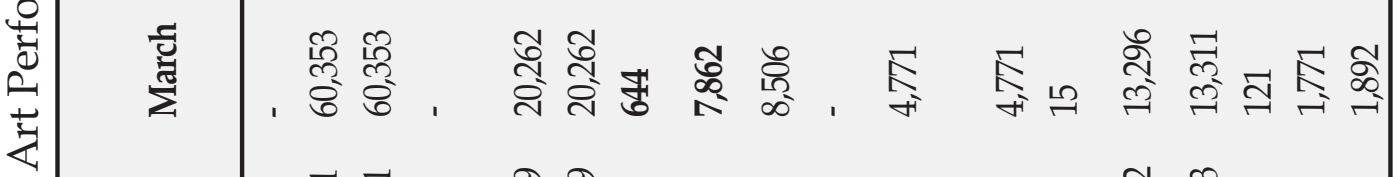

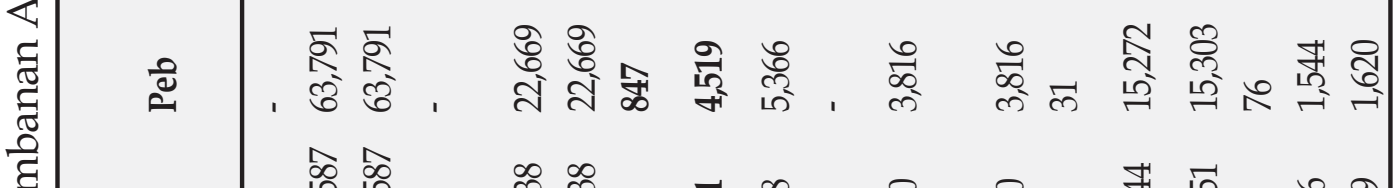

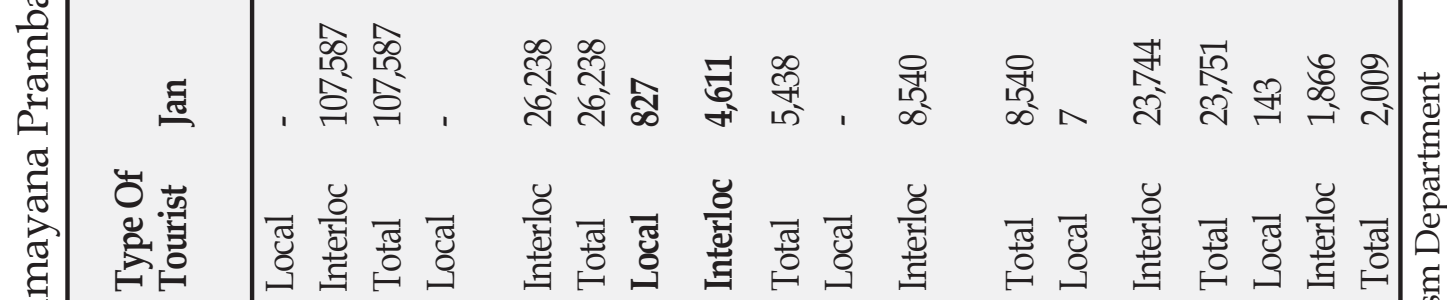

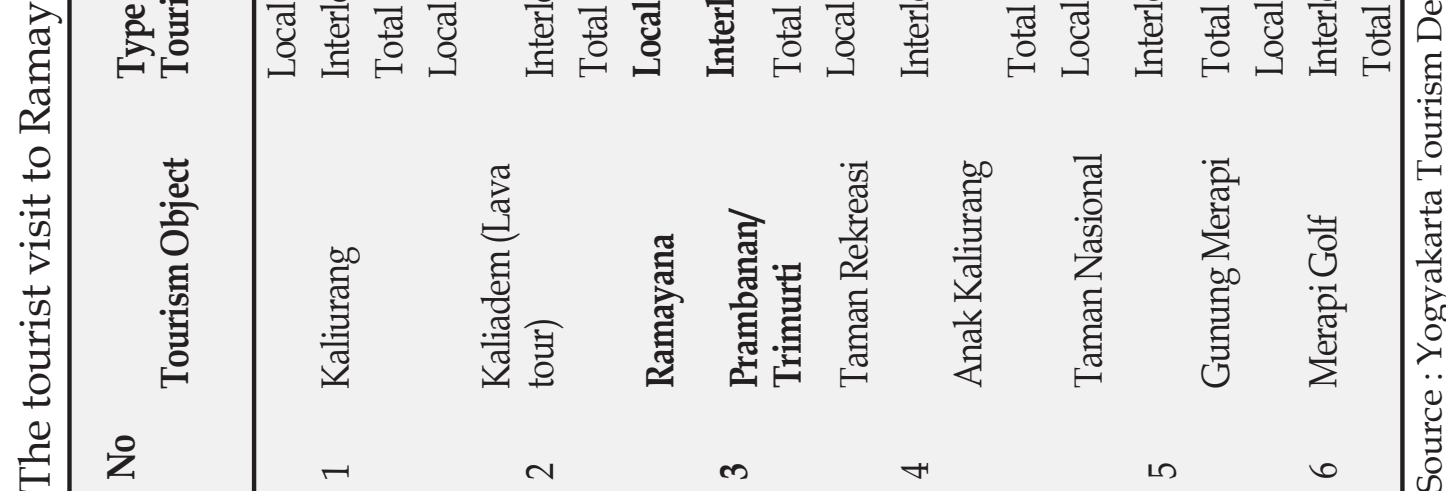


From the data above, we can see that the number of tourists visiting Ramayana Prambanan has increased in the time period from 2007 to 2016. Ramayana Prambanan performing art has become the third most preferred tourist destinations in 2016.

\section{CONCLUSION}

The analysis concerning the internal conditions of the organization can reveal the strengths and weaknesses of the organization, while the development of external factors can create opportunities or threats for the organization (Sari, 2018).

Based on the data analysis and discussion, we can conclude that Ramayana Prambanan as one of performance arts in Yogyakarta has a positive value and provides a significant contribution to Yogyakarta tourism. These can be seen from the increase of tourist visitors for Ramayana Art Performance from 2008 to 2016. The art performance has become one of the best promotional strategy choices in Yogyakarta.

\section{REFERENCES}

[1] Langley, S. (1974). Theatre Management in America (Principle and Practice): Producing for the Commercial, Stock, Resident, College, and Community Theatre. New York: Drama Book Specialists.

[2] Mill, R. C. (1990). Tourism The International Business. Singapore: Prentice Hall, Inc.

[3] Muhadjir, N. (2000). Metodologi Penelitian Kualitatif. Yogyakarta: Rake Sarasin.

[4] Permas, A., Sedyono, C, H., Pranoto, L.H., \& Saputro, T. (2003). Manajemen Organisasi Seni Pertunjukan. Jakarta: Penerbit PPM.

[5] Robbins, S. P., \& DeCenzo, D. A. (2000). Fundamentals of Management. New Jersey: Prentice Hall, Inc.

[6] Sari, C. T. (2018). The Study Of Agricultural Marketing In Art Performance In The Case Of "Festival Pasar Kumandang". UNEJ e-Proceeding.

[7] Soedarsono, R. M. (2003). Seni Pertunjukan dari Perspektif Politik, Sosial, dan Ekonomi. Yogyakarta: Gadjah Mada University Press. 